\title{
Correlation of Maternal Cytophilic Human Immunodeficiency Virus (HIV)-1 V3 Loop Peptide-Specific Antibodies in Infants with Vertical HIV Transmission
}

\author{
XUE-PING WANG, NAOKI OYAIZU, AND SAVITA PAHWA \\ Department of Pediatrics, North Shore University Hospital-Cornell University Medical College,
} Manhasset, New York 11030

\begin{abstract}
Approximately $70 \%$ of human immunodeficiency virus (HIV)-1-infected pregnant women do not transmit HIV to their offsprings. The identification of factors involved in maternalchild transmission of HIV is important for the design and implementation of therapeutic and prevention strategies. Recently we have developed a modified peripheral mononuclear cell (PBMC) culture system for in vitro antibody production (IVAP) by which we can distinguish serum-derived cytophilic anti-HIV-1 antibody from de novo synthesized antibody. In this study, we analyzed the presence of antibodies directed to HIV-1 gp160, gp120, gp41, and V3 loop synthetic peptides (C51, C53, and C57 from MN and IIIB strains) utilizing the grid-blot method in PBMC cultures of 52 mother-child pairs. Among the mothers (39 nontransmitters and 13 transmitters), presence of serum-derived cytophilic antibodies or de novo synthesized HIV V3 loop peptide-specific
\end{abstract}

ABSTRACT
The V3 loop of the HIV-1 gp120 envelope glycoprotein is a disulfide-linked closed loop of about 30 amino acids which contains the principal neutralizing domain for virusneutralizing antibodies (1-3). More importantly, binding of V3 loop with a second cell surface receptor is believed to be essential for entry of HIV into $\mathrm{CD}^{+}{ }^{+}$cells (4). The in vitro characteristics of anti-V3 loop antibodies suggest that this antibody could be itself prevent HIV-1 infection in vivo $(5,6)$. A mouse-human chimeric MAb specific for the V3 loop domain was found to protect chimpanzees against infection with HIV-1 when administered either before or after challenge (7). Antibodies directed to HIV-1 V3 loop have been associated with lower heterosexual transmission from male to female and slower disease progression in infected individuals $(8-10)$. Thus V3 loop-specific antibodies may play an important role in HIV-1 infection. However, the role of antibodies against V3

Received June 13, 1994; accepted March 3, 1995

Correspondence and reprint requests: Dr. S. Pahwa, BioMedical Research Building, Room 303, Department of Pediatrics, Division of Allergy/Immunology, NSUH-CUMC, 350 Community Drive, Manhasset, NY 11030.

Supported by National Institutes of Health Grants HD-26602 and DA-05161. antibodies did not correlate with vertical transmission. However, PBMC-associated, cytophilic antibodies of maternal origin reactive with $\mathrm{C} 51, \mathrm{C} 53$, and $\mathrm{C} 57$ from MN and IIIB strains were identified in cultures of uninfected infants, but not in infected infants. These observations suggest that cytophilic antibodies of maternal origin directed to HIV-1 V3 loop peptides which are bound to infant cells might play a role in preventing vertical transmission. (Pediatr Res 38: 384-389, 1995)

\author{
Abbreviations \\ PBMC, peripheral blood mononuclear cells \\ IVAP, in vitro antibody production \\ TBS, Tris buffered saline \\ gp, glycoprotein
}

loop in protection against vertical transmission of HIV is still controversial (11-19). Recently we have observed that, in HIV-infected individuals, supernatants of cultured PBMC for 1 h contain cytophilic antibodies which are eluted from PBMC. If the PBMC are washed and recultured for $7 \mathrm{~d}$, they secrete de novo synthesized antibody designated as in vitro antibody production or IVAP. It is therefore possible to distinguish "cytophilic" anti-HIV-1 antibody from "de novo" HIV antibody production (20). Maternal derived cytophilic antibodies are identifiable in culture supernatants of PBMC from infants born to HIV-infected women (20). In this study, direct evidence for correlation of anti-V3 loop antibodies with maternalchild transmission was sought in order to determine whether the serum-derived maternal cytophilic antibodies which adhered to the surface of infant's PBMC correlate with occurrence of vertical transmission of HIV. We have analyzed PBMC culture supernatants from 52 mother-infant pairs for the presence of antibodies directed to HIV-1 gp160, gp120, gp41, and V3 loop synthetic peptides C51, C53, and C57 of MN and IIIB strains by utilizing the grid-blot method (21). Our findings suggest that the presence of cytophilic antibodies of maternal 
origin on infant PBMC may play a role in preventing transmission of HIV.

\section{METHODS}

Study group. This study group consists of 52 pairs of HIV-1-infected mothers and their offspring. The infants were clinically monitored for periods of $>18$ mo of age and were determined as being infected or not infected according to the Communicable Disease Center criteria for HIV infection (22). Culture supernatants from PBMC were collected in infants at age $\leq 3 \mathrm{mo}$, the mean age at time of sample collecting from HIV-infected infants was $1.45 \pm 0.65 \mathrm{mo}(n=13)$ and that of HIV-uninfected infants, $1.56 \pm 0.73 \mathrm{mo}(n=39)$. From the mothers, the blood samples were obtained at the same time as the infants. Based on their children's outcome, the mothers were divided into nontransmitting and transmitting groups. A retrospective analyses of antibody determination was performed in culture supernatants as described below.

$P B M C$ culture procedure. PBMC were separated by Ficollhypaque density gradient centrifugation on Lymphoprep (Nucomed, Oslo, Norway) as previously described (20). The cells were washed three times in Hanks' balanced salt solution and resuspended at a concentration of $1 \times 10^{6} / \mathrm{ml}$ in RPMI 1640 supplemented with $10 \% \mathrm{FCS}$, penicillin, and streptomycin. PBMC were then cultured for $1 \mathrm{~h}$ at $37^{\circ} \mathrm{C}$, supernatants collected and designated as " $1-\mathrm{h}$ supernatants" (containing serum-derived cytophilic antibodies). After washing the PBMC again with PBS, cells were resuspended in RPMI with $10 \%$ FCS and cultured for additional $7 \mathrm{~d}$; supernatants were collected and designated as "7-d supernatants" (containing antibodies synthesized de novo). The supernatants were stored at $-20^{\circ} \mathrm{C}$ until assayed for presence of HIV antibodies by grid-blot and ELISA.

HIV-1 envelope glycoproteins and synthetic peptides of V3 loop. HIV-1 envelope glycoproteins gp160 and gp120 were purified from supernatants of HIV-1 ${ }_{451}$-infected clone of Hut 78 cells as described previously (23). Immunodominant peptide from gp41 (JB4 IIIB) and peptides of V3 loop from HIV-1 MN and IIIB strains (C51, C53, C57) were kindly provided by Dr. Paolo Rossi, and the sequences are shown in Table 1. p121 represents a segment of gp41, consisting of 80 amino acids from 566 to 645 (Repligen Corp., Cambridge, MA).

Grid-blot procedure for antibody determination. The gridblot procedure was carried out as described previously (21). Briefly, a wet sheet of nitrocellulose paper previously soaked in Tris buffered saline (TBS) for $20 \mathrm{~min}$ was positioned on the

Table 1. Synthetic peptides from HIV-I V3 loop used for this study

\begin{tabular}{cccl}
\hline & $\begin{array}{c}\text { First } \\
\text { Peptide name }\end{array}$ & $\begin{array}{c}\text { Last amino } \\
\text { acid }\end{array}$ & \multicolumn{1}{c}{ Sequence } \\
\hline C51 MN & 294 & 308 & INCTRPNYNTRKRTH \\
C51 IIIB & 294 & 308 & INCTRPNNNTRKSIR \\
C53 MN & 306 & 320 & RKRIHIGPGRAFYTT \\
C53 IIIB & 304 & 318 & RKSIRIQRGPGRAFV \\
C57 MN & 325 & 339 & TIRQAHCNISRAKWN \\
C57 IIIB & 324 & 338 & GNMRQAHCNISRAKW \\
JB4 IIIB & 598 & 617 & GIWGCSGKLTCTTAVPWNAS \\
\hline
\end{tabular}

slotted portion of the acrylic plate of a SURF-BLOT apparatus (Idea Scientific Co., Minneapolis, MN). The foam pad followed by the metal plate of the apparatus were then stacked against the back of the nitrocellulose sheet and the apparatus clamped securely. HIV gp160, gp120, and the desired peptides, dissolved in TBS $(3 \mu \mathrm{g} / \mathrm{ml})$ were applied to each channel in $100 \mu \mathrm{l}$ volumes. The SURF-BLOT was then incubated for 60 min on a plateform shaker. The channels were washed twice with TBS and the apparatus disassembled. The antibody screening was performed by first blocking the nitrocellulose sheet in Blotto (2\% non-fat milk in TBS) for $60 \mathrm{~min}$ followed by assembly of the sheet in the SURF-BLOT apparatus as described above, except that the sheet was rotated $90^{\circ}$ clockwise so that the channels were now oriented at right angles to the row of absorbed specific antibody on the nitrocellulose sheet. One hundred microliters of supernatant were added to each channel. The SURF-BLOT was incubated for $60 \mathrm{~min}$ as before, the channels were washed, and the device was disassembled. To visualize the anti-V3 loop IgG, the nitrocellulose sheets were incubated with alkaline phosphatase-conjugated goat-anti-human $\operatorname{IgG}$ (1:1000 dilution) for $60 \mathrm{~min}$, washed in TBS, and visualized with the 5-bromo-4-chloro-3-indolyl phosphate and nitro blue tetrazolium.

ELISA for detecting anti-HIV-1 gp160 IgG in supernatants. The method followed was essentially as described previously (20). Briefly, culture supernatants were added in duplicate wells to the plates coated with HIV-1 gp160 and incubated for $1 \mathrm{~h}$ at $37^{\circ} \mathrm{C}$. Bound anti-gp $160 \mathrm{IgG}$ was detected by alkaline phosphatase-conjugated goat $\mathrm{F}\left(\mathrm{ab}^{\prime}\right)_{2}$ anti-human IgG antibody (Tago Inc., Burlingame, CA). The OD of absorbance was measured at $405 \mathrm{~nm}$ on a microplate reader (Coulter Electronics Inc., Hialeah, FL) and analyzed on the Softmax ELISA program (Molecular Devices, Menlo Park, CA).

Statistical analysis. Comparisons of the OD value from HIV-1 gp160 ELISA were made between the transmitting and nontransmitting groups of mothers and infected and uninfected infants. The data were analyzed using the unpaired $t$ test. For determination of differences in reactivity to HIV-1 V3 loop peptides between the groups, Fisher's exact test was performed.

\section{RESULTS}

Sensitivity of grid-blot. The grid-blot assay can be adapted to screen antibody reactivities to a wide range of peptides or antigens for study of humoral immunity in serum and/or culture supernatants (21). In this study, the sensitivity was assessed by HIV-1 envelope gp41 and anti-gp41 MAb (p121 and MAb 2A2, respectively): the limitation of detecting antibody was $1.56 \mathrm{ng} / \mathrm{ml}$ when P121 antigen (3 $\mu \mathrm{g} / \mathrm{ml}$ ) was loaded on nitrocellulose. One hundred percent sensitivity was obtained when applying this assay to detect anti-HIV IgG in IVAP supernatants from $\mathrm{HIV}^{+}$individuals (24). Typical results of grid-blot for detecting IgG antibodies against HIV-1 gp160, gp120, JB4 IIIB, and peptides from V3 loop in IVAP supernatants from maternal-child pairs are shown in Figure 1. 


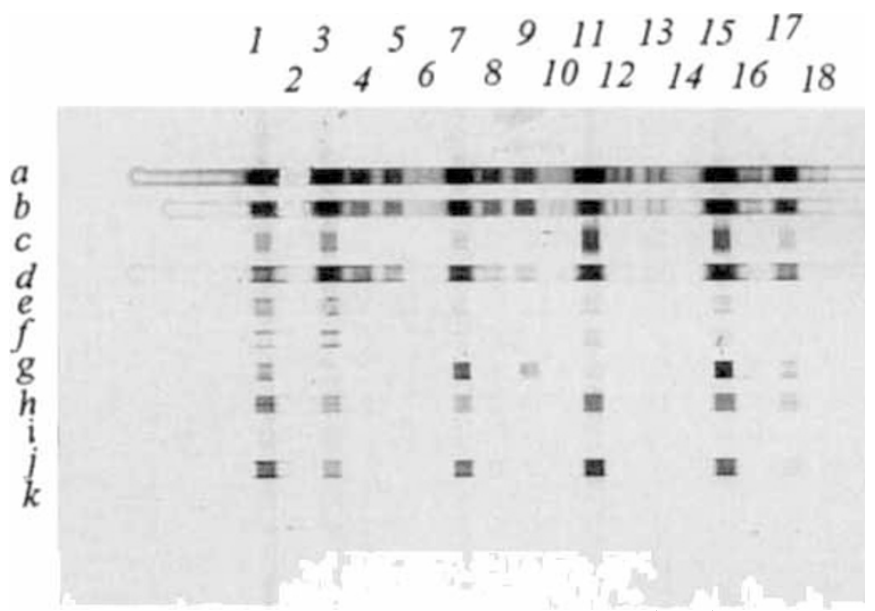

Figure 1. Typical result of grid-blot in the modified IVAP supernatants from mother-infant pairs. Row (HIV-1 envelope glycoproteins and V3 loop peptides): $a$, gp160; $b$, gp120; $c$, JB4-IIIB (gp41); $d$, P121 (gp41); e, C51 MN; $f$, C51 IIIB; $g$, C53 MN; $h$, C53 IIIB; $i$, C57 MN; $j$, C57 IIIB; $k$, TBS. Lane (supernatants): 1 , positive control; 2 , negative control; 3,1 -h supernatant (sup) from 215 mother; 4, 7-d sup from 215 mother; 5, 1-h sup from 215 infant (HIV-1 infected); 6, 7-d sup from 215 infant; 7, 1-h sup from 221 mother; 8, 7 -d sup from 221 mother; 9, 1-h sup from 221 infant (HIV-1 uninfected); 10 7 -d sup from 221 infant; 11,1 -h sup from 220 mother; 12,7 -d sup from 220 mother; 13, 1-h sup from 220 infant (HIV-1 uninfected); 14, 7-d sup from 220 infant; 15, 1-h sup from 224 mother; 16, 7-d sup from 224 mother; 17, 1-h sup from 224 infant (HIV-1 uninfected); 18, 7-d sup from 224 infant. HIV-1 V3 loop C53 MN-, C53 IIIB-, and C57 IIIB-specific antibodies can be detected in 1-h supernatants from HIV-1-uninfected infants 221 (lane 9) and 224 (lane 17)

Presence of anti-V3 loop antibodies in PBMC supernatants from mothers did not correlate with vertical transmission. We have demonstrated that the revised culture procedure of PBMC for IVAP could distinguish between serum-derived cytophilic anti-HIV antibodies which adhere to the surface of PBMC and are released into the 1-h supernatants from those synthesized de novo and are secreted into the 7-d supernatants (20). When the 1-h supernatants from PBMC of transmitting and nontransmitting mothers are analyzed for antibodies to HIV-1 by ELISA and grid-blot, the results did not show any significant difference between the two groups; the OD values for anti-HIV-1 gp160 IgG ELISA were $1.32 \pm 0.73$ in nontransmitters and $1.35 \pm 0.63$ in transmitters (Fig. 2). Reactivity

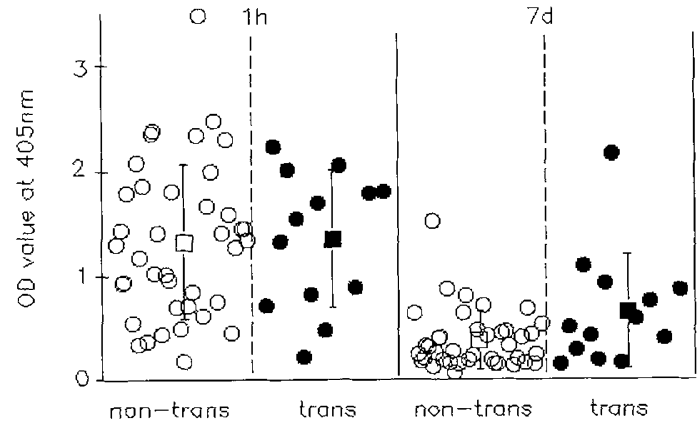

Figure 2. HIV-1 gp160 antibody determination by ELISA in nontransmitting and transmitting mothers. The 1 -h supernatants (left) and $7-d$ supernatants (right) of PBMC cultures from nontransmitting and transmitting mothers were assayed for anti-HIV-1 gp160 IgG by ELISA. The OD values were not significantly different in the two groups of mothers. to HIV-1 gp160, gp120, gp41, and V3 loop peptides C51, C53, and C57 from MN and IIIB strains in the two groups are shown in Table 2, and no difference was noted between them.

The 7-d supernatants which contain anti-HIV antibodies produced by PBMC in vitro and represent a humoral immune response to HIV infection were analyzed by ELISA and gridblot. No significant differences were observed between the nontransmitter and transmitter groups; the OD values from anti-HIV-1 gp160 IgG ELISA were $0.37 \pm 0.28$ and $0.59 \pm$ 0.54 , respectively $(t=1.91 p>0.05)$ (Fig. 2). Reactivities to HIV-1 gp160, gp120, gp41, and V3 loop peptides C51, C53, and $\mathrm{C} 57$ from MN and IIIB strains from the 7-d supernatants were also not different in the two groups (Table 3).

Correlation of maternally serum-derived cytophilic anti-V3 loop antibodies in PBMC supernatants of infants with vertical transmission. We analyzed anti-HIV gp160 IgG and antibodies against HIV V3 loop peptides in 1-h culture supernatants of PBMC from infants. Cytophilic antibodies of maternal origin have been shown previously to be released in these supernatants (20). Results show that antibodies against HIV-1 V3 loop peptides (C51, C53, and C57 from MN and IIIB strains) could be detected only in noninfected infants (Table 4). Of 39 seroreverters, 17 had antibodies to 1 or more V3 loop peptides. In their 1-h supernatants, antibody to C53 MN was the most frequent and was detectable in 1-h supernatants of 14 infants $(p<0.05)$. None of the infected infants had detectable V3 loop peptide antibodies in their 1-h supernatants. The mean OD of anti-HIV gp160 in 7-d supernatants which represent de novo antibody production was $0.04 \pm 0.02$ in noninfected infants, and $0.132 \pm 0.277$ in infected infants $(t=2.13, p<$ 0.05) (Fig. 3). Anti-HIV gp160 IgG in the 1-h supernatants was not different between noninfected and infected infants, the mean OD being $0.51 \pm 0.44$ and $0.52 \pm 0.57$, respectively (Fig. 3). These results were also confirmed in reactivity to HrV gp160 by grid-blot.

\section{DISCUSSION}

Transplacental transfer of maternal antibodies to infants is known to be an important component of protective immunity against a variety of infectious agents. However, the role of anti-HIV antibodies in vertical transmission of HIV is unclear. In this study, we have demonstrated that maternally derived HIV V3 loop directed antibodies adhering to infant PBMC, when present, were associated with a lack of infection in the infants.

We have previously observed (20) that 1 -h supernatants from cultured PBMC contain serum-derived cytophilic antibodies which are released from the surface of the PBMC. If these cells were washed and recultured, then no HIVspecific antibody was detected in 24-h supernatants either in infected or uninfected infants; HIV-specific antibody was detectable in 7-d culture supernatants only from HIVinfected infants, representing de novo antibody secretion. HIV-1-specific antibodies detectable in 1-h supernatants of PBMC from uninfected infants were demonstrated to be maternal in origin. We investigated the relationship of maternal HIV V3 loop-specific antibodies with vertical 
Table 2. Presence of cytophilic anti-V3 loop antibodies in PBMC supernatants from mothers did not correlate with vertical transmission

\begin{tabular}{|c|c|c|c|c|c|c|c|c|}
\hline \multirow[b]{3}{*}{$\mathrm{gp} 160$} & \multirow[b]{3}{*}{ gp120 } & \multirow[b]{3}{*}{ JB4IIIB } & \multicolumn{6}{|c|}{ No. of supernatants reactive by grid-blot to: } \\
\hline & & & \multicolumn{2}{|c|}{ C51 } & \multicolumn{2}{|c|}{$\mathrm{C} 53$} & \multicolumn{2}{|c|}{$\mathrm{C} 57$} \\
\hline & & & $\mathrm{MN}$ & IIIB & MN & IIIB & MN & IIIB \\
\hline \multicolumn{8}{|l|}{ Nontransmitters } & $10 / 39(26)$ \\
\hline \multicolumn{9}{|l|}{ Transmitters } \\
\hline $13 / 13(100)$ & $13 / 13(100)$ & $13 / 13(100)$ & $5 / 13(39)$ & $5 / 13(39)$ & $6 / 13(46)$ & $6 / 13(46)$ & $4 / 13(31)$ & 6/13 (46) \\
\hline
\end{tabular}

The V3 loop peptide-specific antibodies in 1-h PBMC supernatants from mothers which contain serum-derived cytophilic antibodies were detected by grid-blot; 39 mothers had HIV-uninfected infants (nontransmitters), 13 mothers had HIV-infected infants (transmitters). Numbers in parentheses indicate percentages showing positive results.

Table 3. Presence of de novo synthesized specific antibodies to V3 loop peptides in PBMC supernatants from mothers did not correlate with vertical transmission

\begin{tabular}{|c|c|c|c|c|c|c|c|c|}
\hline \multicolumn{9}{|c|}{ No. of supernatants reactive by grid-blot to: } \\
\hline \multirow[b]{2}{*}{ gp160 } & \multirow[b]{2}{*}{$\mathrm{gp} 120$} & \multirow[b]{2}{*}{ JB4IIIB } & \multicolumn{2}{|c|}{ C51 } & \multicolumn{2}{|c|}{$\mathrm{C} 53$} & \multicolumn{2}{|c|}{ C57 } \\
\hline & & & $\mathrm{MN}$ & IIIB & $\mathrm{MN}$ & IIIB & $\mathrm{MN}$ & IIIB \\
\hline \multicolumn{9}{|l|}{ Nontransmitters } \\
\hline $34 / 39(87)$ & $23 / 39(59)$ & $18 / 39(46)$ & $7 / 39(18)$ & $2 / 39 \quad(5)$ & $5 / 39(13)$ & $3 / 39 \quad(8)$ & $3 / 39 \quad(8)$ & $4 / 39 \quad(8)$ \\
\hline \multicolumn{9}{|l|}{ Transmitters } \\
\hline $11 / 13(85)$ & $12 / 13(92)$ & $6 / 13(46)$ & $3 / 13(23)$ & $2 / 13(16)$ & $2 / 13(16)$ & $2 / 13(16)$ & $2 / 13(16)$ & $2 / 13(16)$ \\
\hline
\end{tabular}

The V3 loop peptide-specific antibodies in 7-d PBMC supernatants from mothers which contain de novo synthesized antibodies were detected by grid-blot; 39 mothers had HIV-uninfected infants (nontransmitters), 13 mothers had HIV-infected infants (transmitters). Numbers in parentheses indicate percentages showing positive results.

Table 4. Anti-V3 loop cytophilic antibodies of maternal origin in PBMC cultures of infants correlated with lack of HIV transmission

\begin{tabular}{|c|c|c|c|c|c|c|c|c|}
\hline \multirow[b]{3}{*}{ gp160 } & \multirow[b]{3}{*}{ gp120 } & \multirow[b]{3}{*}{ JB4IIIB } & \multicolumn{6}{|c|}{ No. of supernatants reactive by grid-blot to: } \\
\hline & & & \multicolumn{2}{|c|}{ C51 } & \multicolumn{2}{|c|}{$\mathrm{C} 53$} & \multicolumn{2}{|c|}{ C57 } \\
\hline & & & MN & IIIB & MN & IIIB & MN & IIIB \\
\hline \multicolumn{9}{|c|}{ HIV-exposed but not infected } \\
\hline $38 / 39 \quad(97)$ & $30 / 39(77)$ & $21 / 39(54)$ & $5 / 39(13)$ & $2 / 39(5)$ & $14 / 39(36)^{*}$ & $7 / 39(18)$ & $1 / 39(3)$ & $4 / 39(10)$ \\
\hline \multicolumn{9}{|l|}{ HIV-infected } \\
\hline $13 / 13(100)$ & $10 / 13(77)$ & $7 / 13(54)$ & $0 / 13 \quad(0)$ & $0 / 13(0)$ & $0 / 13(0)$ & $0 / 13(0)$ & $0 / 13(0)$ & $0 / 13(0)$ \\
\hline
\end{tabular}

The V3 loop peptide specific antibodies in 1-h PBMC supernatants from infants $(<3$ mo) which contain cytophilic antibodies of maternal origin were determined by grid-blot; 39 infants seroreverted (not infected), 13 infants were HrV-infected. Numbers in parentheses indicate percentages showing positive results.

* A significant difference was noted between not infected and infected infants for anti-C53 MN peptide antibody, $p<0.05$.

transmission in PBMC culture supernatants from motherinfant pairs. The grid-blot method was selected because of the ease with which screening for antibodies to different HIV-1 envelope gp and V3 peptides could be performed using $100 \mu \mathrm{l}$ of the culture supernatant.

In the 52 mothers studied (39 nontransmitter and 13 transmitter), presence of serum-derived cytophilic antibodics or de novo synthesized HIV V3 antibodies in maternal PBMC cultures did not correlate with vertical transmission. However, in the PBMC of their infants, serum-derived maternal cytophilic antibodies directed to C51, C53, and C57 from MN and IIIB strains, most prominently C53 MN antibody could be eluted only from cells of uninfected infants, but not of infected infants. These observations suggest that cytophilic antibodies of maternal origin directed to HIV-1 V3 loop peptides are transferred selectively and get bound to infant cells. Whether or not such cytophilic binding of antibody occurs may depend on as yet undetermined characteristics of antibodies, e.g. anti- body affinity or the presence of viral replication in the infected children which might have resulted in a decrease in HIVspecific antibody available for binding to Fc-bearing cells. The protective mechanism is also speculative; presence of antibody on target cells could, for instance, protect the cells from virus entry.

The reactivity to HIV gp160, gp120, gp41 (JB4IIIB), and V3 loop peptides in 1-h supernatants from mothers in both groups was detected. Although the trend for a higher reactivity to C53 $\mathrm{MN}$ in 1-h supernatants was observed in nontransmitting mothers, these results provide evidence that presence of HIV V3 loop-specific antibody in the mothers does not correlate with lower vertical transmission. This finding is consistent with recent reports indicating that HIV V3-specific antibody in mothers did not reveal a correlation with prevention from HIV infection in their offsprings (14, 16-19). Additionally, in the present study, humoral immunity to HIV infection in mothers as evaluated by de novo antibody synthesis was also not related 


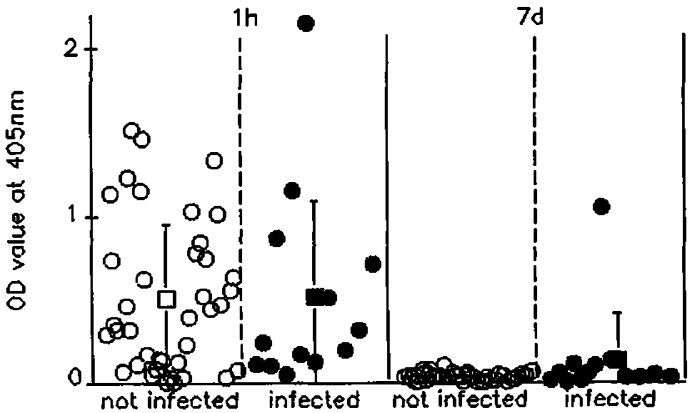

Figure 3. HIV-1 gp160 antibody determination by ELISA in HIV-infected and uninfected infants. The 1-h supernatants (left) and 7-d supernatants (right) of PBMC cultures from HIV-uninfected and infected infants were assayed for anti-HIV-1 gp160 IgG by ELISA. Cytophilic anti-gp160 antibody (1-h supernatant) was similar in the two groups. As expccted, IVAP was detectable only in infected infants $(0.132 \pm 0.28)$, not in the uninfected infants $(0.04 \pm 0.02)$, $p<0.05$.

with vertical transmission, since the levels were equivalent in transmitting and nontransmitting mothers.

Among previous published reports about maternal HIV V3specific antibodies with vertical transmission, three studies screened reactivity to $V 3$ loop peptides in serum from infants by ELISA: two studies found that maternal HIV V3 specific antibodies in serum from infants correlated with low vertical transmission $(12,13)$, whereas one did not observe a significant difference between infected and uninfected infants (19). In our study, maternally derived cytophilic HIV-1 V3 specific antibodies could only be detected in some and not all uninfected infants which suggests that cytophilic antibodies specific for different V3 loop sequence might be present on infant PBMC and/or that other factors are of importance in protection from vertical transmission. Factors which have been shown to play a role in transmission of infection from mother to infants include maternal CD4 count, virus burden in the mothers (25) and HIV-specific immunity in the fetus (26). Factors affecting timing of transmission may have an overriding influence on protective role of humoral immunity, because placental transfer occurs only late during the third trimester and a fraction of infants does appear to get infected early in gestation (27).

In our study, cross-reactivity to V3 loop peptides from MN and IIIB strains was observed, although the predominant strain in the present study was MN. The cross-reactivity is a common phenomenon among HIV-1 V3-specific antibodies, and the predominant reactivity to the MN strain is consistent with the high prevalence of HIV MN-related viruses in the United States $(28,29)$.

Our results suggest that, although the "presence" of maternal HIV V3-specific antibodies in mothers may of itself not correlate with vertical transmission, their adherence to infant PBMC may play a role in prevention of HIV vertical transmission.

Acknowledgments. The authors thank Dr. Paolo Rossi for the generous gifts of HIV V3 loop peptides.

\section{REFERENCES}

1. Rusche JR, Javaherian K, Mcdanal C, Petro J, Lynn DL, Grimaila R, Langlois A Gallo RC, Arthur LO, Fischinger PJ, Bolognesi DP, Putney SD, Matthews TJ 1988
Antibodics that inhibit fusion of human immunodeficiency virus-infected cclls bind a 24-amino acid scquence of the viral envelope, gp120. Proc Natl Acad Sci USA 85:3198-3202

2. Goudsmit J, Debouck C, Melocn RH, Smit L, Bakker M, Asher DM, Wolff AV, Gibbs CJ, Gajdusck DC 1988 Human immunodeficiency virus type 1 neutralization epitope with conserved architcclure elicits early type-specific antibodies in experimentally infected chimpanzees. Proc Natl Acad Sci USA 85:4478-4482

3. Palker TJ, Clark ME, Langlois AJ, Matthcws TJ, Wcinhold KJ, Randall RR, Bolognesi DP, Haynes BP 1988 Type-specific neutralization of the human immunodeficiency virus with antibodics to env-encoded synthetic peptides. Proc Natl Acad Sci USA 85:1932-1936

4. Callebaut C, Krust B, Jacolot E and Hovanessian AG $1993 \mathrm{~T}$ cell activation antigen, CD26, as a cofactor for entry of HIV in CD4 ${ }^{+}$cells. Science 262:2045-2050

5. Linsley PS, Ledbetter JA, Kinney-Thomas E, HU S-L 1988 Effecl of anti-gp 120 monoclonal antibodies on CD4 receptor binding by the env protein of human immunodeficiency virus type 1. J Virol 62:3695-3701

6. Skinner MA, Langlois AJ, Mcdanal CB, Mcdougal JS, Bolognesi DP, Matthews TJ 1988 Neutralizing antibodies to an immunodominant envelope sequence to not prevent gp120 binding to CD4. J Virol 62:4195-4200

7. Emini EA, Schleif WA, Nunberg JH, Conley AJ, Eda Y, Tokiyoshi S, Putncy SD, Matsushita S, Cobb KE, Jeff CM, Eichherg JW, Murthy KK 1992 Prevention of HIV-1 infection in chimpanzees by gp120 V3 domain-specific monoclonal antibody. Nature 355:728-730

8. Fiorc JR, Jansson M, Scarlatti G, Angarano G, Caputo SL, Buccoliero G, Rossi P, Fenyo EM, Pastore G 1993 Correlation between scroreactivity to HIV-I V3 loop peptides and male-10-female hetcrosexual transmission. AIDS 7:29-31

9. Page M, Vella C, Corcoran T, Dilger P, Ling C, Heath A, Thorpe R 1992 Restriction of serum antibody reactivity to the V3 neutralizing domain of HIV gp120 with progression to AIDS. AIDS 6:441-446

10. Robert-Guroff M, Roilides E, Muldoon R, Venzon D, Husson R, Pizzo PA 1993 Human immunodeficicncy virus (HIV) type 1 strain $M N$ ncutralizing antibody in HIV-infected children: Correlation with clinical status and prognostic valuc. J Infect Dis 167:538-546

11. Goedert JJ, Mendez H, Drummond JE, Robert-Guroff M, Minkoff HL, Holman S, Stevens R, Rubinstcin A, Blattner WA, Willoughby A, Landesman SH 1989 Motherto-infant transmission of human immunodeficiency virus type 1: Association with prematurity or low anti-gp120. Lancet 2:1351-1354

12. Rossi P, Moschesc V, Broliden PA, Fundaro C, Quinti I, Plebani A, Giaquinto C Tovo PA, Ljunggren K, Rosen J 1989 Presence of maternal antibodies to human immunodeficiency virus 1 envelope glycoprotein gp120 epitopes correlates with the uninfected status of children born to seropositive mothers. Proc Natl Acad Sci USA 86:8055-8058

13. Devash Y, Cavelli TA, Wood DG, Reagen KJ, Rubinstcin A 1990 Vcrtical transmission of human immunodeficiency virus is correlated with absence of high affinity/ avidity maternal antibodies to the gp120 principal neutralizing domain. Proc Natl Acad Sci USA 87:3445-3449

14. Parckh BS, Shaffer N, Pau CP, Abrams E, Thomas P, Pollack H, Bamji M, Kaul A Schochetman G, Rogers M 1991 Lack of correlation between maternal antibodies to V3 loop peptides of gp120 and perinatal HIV-1 transmission. AIDS 5:1179-1184

15. Ugen K, Goeder JJ, Boyer J, Relacli Y, Frank I, Williams W, Willoughby A, Landesman S, Mendez H, Rubinstcin A, Kiebcr-Emmons T, Weiner DB 1992 Vertical transmission of human immunodeficiency virus (HIV) infection. J Clin Invest 89:1923-1930

16. Robertson CA, Mok JYQ, Frocbel KS, Simmonds P, Burns SM, Marsden HS, Graham S 1992 Matcrnal antibodics to gpl20 V3 sequence do not corrclate with protection against vertical transmission of human immunodeficiency virus. J infect Dis 166:704-709

17. Rubinstein A, Goldstein H, Calvelli T, Devash Y, Rubinstein R, Sociro R, Lyman W 1993 Maternofetal transmission of human immunodeficiency virus-1: The rolc of antibodics to the V3 primary neutralizing domain. Pcdiatr Res 33:S76-S79.

18. Halscy NA, Markham R, Wahren B, Boulos R, Rossi P, Wigzell H 1992 Lack of association between maternal antibodies to $\mathrm{V} 3$ loop peptides and matcrnal-infant HIV-1 transmission. J Acquircd Immune Defic Syndr 5:153-157

19. De Ross A, Zanotto C, Mammano F, Ometto L, Del Mistro A, Chieco-Bianchil L 1993 Pattern of antibody response against the V3 loop in children with vertically acquired immunodeficiency virus type I (HIV-1) infection. AIDS Res Hum Retroviruses 9:221-228.

20. Wang X-P, Paul M, Tetali S, Abrams E, Bamji M, Gulick L, Chirmule N, Oyaizu N and Pahwa S 1994 Improved specificily of in vitro anti-HIV antibody production (IVAP): Implications for implications for diagnosis and timing of transmission in infants born to HIV-seropositive mothcrs. AIDS Res Hum Retroviruses 10:679-687.

21. Lane RD, Mcllgren RL, Hegazy MG, Gonzales SR, Nepomuceno V, Rcimann EM, Schlcnder KK 1989 The grid-blot: A procedure for screening large numbers of mAbs for specificity to native and denatured proteins. Hybridoma 8:661-669

22. Centers for Disease Control 1987 Classification system for human immunodeficiency virus (HIV) infection in children under 13 years of agc. Morbid Mortal Wkly Rep 36:225-235

23. Kalyanaraman VS, Rodrigues V, Veronese $F$, Rahman $R$, Lusso $P$, Devico $A L$ Copeland T, Oroszlan S, Gallo RC, Sarnganaran MG 1990 Characterization of the secreted native $\mathrm{gp} 120$ and gp 160 of the human immunodeficiency virus type 1. AIDS Rcs Hum Retroviruses 6:371-380

24. Shearer GM, Clerici M, Bcrzofsky JA, Pahwa S, Chess L, Lcderman S et al 1993 HIV exposure in long-term non-seroconverting homosexual men at risk for HIV infection. IX. International Conference on AIDS Burlin Abstract Book: abstr WS-A09-4

25. European Collaborative Study 1992 Risk factors for mother-to-child transmission of HIV-1. Lancet 339:1007-1012 
26. Clerici M, Sison AV, Berzofsky JA, Rakusan TA, Brandt CD, Ellaurie M, Villa M, Colie C, Venzon DJ, Sever JL, Shearer GM 1993 Cellular immun factors associated with mother-to-infant transmission of HIV. AIDS 7:1427-1433

27. Krivine A, Frition G, Cao L, Francoual C, Henrion R and Lebon P 1992 HIV replication during the first weeks of life. Lancet 339:1187-1189

28. Devash Y, Matthews JJ, Drummond JE, Javaherian K, Waters DJ, Arthur LO, Blattner WA, Rusch JR 1990 C-terminal fragments of gp120 and synthetic peptides from five HILV-III strains: Prevalence of antibodies to the HTLV-III MN isolate in infected individuals. AIDS Res Hum Retroviruses 6:307-316

29. La Rosa GJ, Davide JP, Weinhold K, Waterbury JA, Profy AT, Lewis JA, Langlois AJ, Dreesman GR, Boswell RN, Shaddluck P, Holley LH, Karpus M, Bolognesi DP, Matthews TJ, Emini AE, Putney SD 1990 Conserved sequence and structural elements in the HIV-1 principal neutralizing domain. Science 249:932935 